\title{
INTERFERENSI GRAMMATIKAL BAHASA INDONESIA DALAM BAHASA INGGRIS: KASUS PADA BUKU LKS BAHASA INGGRIS UNTUK SLTP DI SURAKARTA
}

\author{
Endang Fauziati \\ Fakultas Keguruan dan Ilmu Pendidikan \\ Universitas Muhammadiyah Surakarta Jl. A. Yani Tromol Pos 1 Pabelan Surakarta \\ Endang.fauziati@ums.ac.id
}

\begin{abstract}
The present study deals with Indonesian interference in English. It aims at giving a thick explanation about grammatical interference which especially exists in English Workbooks for Junior High School students in Surakarta. The data consist of sentences containing interference taken from 10 English workbooks as data source. There were 185 sentences collected as data which were analyzed using error analysis framework and sociolinguistic perspective. The research findings show that there were seven types of grammatical interference: mismatching (62/33.51\%), preposition (35/18.91\%), superflous expression (27/14.59\%), parallel construction (21/11.35\%), passive (17/918\%), conjunction (14/7.56\%), and modifier and adverb (9/4.86\%). Only one out of 10 workbooks, that is LKS Bahasa Inggris by MGMP, contained no language interference. The other 9 books contained language interference with the highest frequency occurred in LKS Bahasa Inggris RABEL (45/24.32\%) and the lowest in LKS Bahasa Inggris Komunikasi Aktif (1/0.5\%). The study also shows that the interference was due to two factors: the bilinguality of the book writers and the tendency of transferring old linguistic behavior in the new one (from Indonesian to English), which basically due to the writers' constrains in English grammar.
\end{abstract}

Keywords: language interference, grammatical interference, causes of interference

\begin{abstract}
ABSTRAK
Penelitian ini berkaitan dengan interferensi Bahasa Indonesia dalam Bahasa Inggris. Tujuan penelitian ini adalah untuk memberikan penjelasan tentang interferensi tata bahasa yang ditemukan dalam Buku Kerja Siswa Bahasa Inggris untuk SMP di Surakarta. Data terdiri dari kalimat yang mengandung interferensi yang diambil dari 10 buku sebagai sumber data. Ada 185 kalimat dikumpulkan sebagai data yang dianalisis menggunakan kerangka analisis kesalahan dan perspektif sosiolinguistik. Hasil penelitian menunjukkan bahwa ada tujuh jenis interfernsi gramatikal: yang meliputi mismatching (62 kasus/ 33,51\%), pengunaan preposisi (35 kasus/ 18,91\%), ekspresi yang berlebih (27 kasus/ 14,59\%), konstruksi paralel (21 kasus/ 11,35\%), konstruksi pasif (17 kasus/ 918\%), penggunaan konjungsi (14 kasus/ 7.56\%), dan penggunaan kata keterangan (9 kasus/ 4,86\%). Hanya satu dari 10 buku, yaitu LKS Bahasa Inggris oleh MGMP, yang tidak mengandung interferensi. Sedangkan 9 buku lainnya yang mengandung interferensi dengan frekuensi tertinggi adalah Bahasa Inggris Rabel (45 kasus/ 24,32\%) dan yang terendah Bahasa Inggris Komunikasi Aktif ( 1 kasus/ 0,5\%). Faktor yang berkontribusi pada intereferensi tata bahasa ini adalah: bilingualitas penulisnya dan kecenderungan mentransfer perilaku linguistik yang
\end{abstract}


lama pada perilaku baru (dari bahasa Indonesia ke bahasa Inggris). Pada dasarnya ini semua dikarenakan oleh kendala penulis terhadap tata bahasa Bahasa Inggris.

Kata Kunci: interferensi bahasa, interferensi gramatikal, menyebabkan interferensi gramatikal

\section{PENDAHULUAN}

Pengguna Bahasa Inggris (BIng) sebagai bahasa asing di Indonesia yang berlatar belakang kebahasaan Bahasa Indonesia (BInd) cukup banyak jumlahnya. Di antara mereka termasuk para guru SMP di Surakarta. Keadaan itu, secara sosiolinguistis, akan menimbulkan terjadinya kontak bahasa, yaitu antara BIng dan BInd, sebagai akibatnya, interferensi pun akan muncul, baik secara lisan maupun secara tertulis. Dalam hal ini, dua buah bahasa disebut berada dalam kontak jika setiap bahasa itu digunakan secara bergantian oleh penuturnya (Weinreich, 1970; Appel and Muysken, 2006).

Pengguanaan Bahasa Indonesia dalam Bahasa Inggris oleh penutur Bahasa Indonesia dapat dikaji dengan menggunakan berbagai perspektif, antara lain perspektif linguistik terapan dan sosiolinguistik. Dalam kajian linguistik terapan, atau pembelajaran bahasa, fenomena tersebut disebut sebagai transfer bahasa ibu. Sementara itu, dalam perspektif sosiolinguistik, fenomena tersebut disebut sebagai interferensi bahasa atau pengaruh bahasa. Pada penelitian sekarang ini fenomena tersebut dikaji dengan kerangka pendekatan sosiolingustik.

Interferensi pada dasarnya merupakan gejala kebahasaan yang lazim terjadi dalam suatu bahasa, khususnya yang digunakan dalam masyarakat yang bilingual ataupun masyarakat yang multilingual. Interferensi adalah penyimpangan dari norma bahasa yang terjadi dalam tuturan dwibahasawan sebagai akibat pengenalan lebih dari satu bahasa atau karena adanya kontak bahasa (Weinreich, 1970; Appel and Muysken, 2006).

Meskipun oleh Weinreich (1970), Mackey (1970), Haugen (1978) dan Appel \& Muysken (2006) secara implisit disebutkan bahwa interferensi lazim terjadi dalam tuturan (lisan), tidak tertutup kemungkinan adanya interferensi yang terjadi dalam bentuk tulisan. Dalam hal ini, interferensi terjadi dalam bentuk lisan jika penutur yang dwibahasawan menggunakan bahasa itu secara lisan. Sebaliknya, jika dia menggunakan bahasa secara tertulis, interferensi itu pun terjadi dalam bentuk tertulis.

Dalam penelitian ini data yang digunakan didasarkan pada sumber tertulis, yakni berupa Buku Lembar Kerja Siswa (LKS) yang digunakan oleh siswa SMP di Surakarta. Hal yang ingin diamati dalam penelitian ini adalah interferensi bahasa Indonesia yang terjadi dalam buku LKS berbahasa Inggris.

Sejauh pengamatan yang dilakukan peneliti, penelitian mengenai interferensi BInd dalam BIng sudah cukup banyak dilakukan oleh para pakar bahasa. Soetomo (1985), misalnya, dalam penelitiannya yang berjudul "Telaah Sosial Budaya terhadap Interferensi, Alih Kode, dan Tunggal Bahasa dalam Masyarakat Ganda Bahasa" (1985), ada dua hal pokok yang ditelaah, yaitu masalah teori dan masalah pengkajian data penelitiannya. Berkenaan dengan masalah teori, Soetomo menelaah sejumlah teori tentang kedwibahasaan, interferensi, alih kode, dan ganda bahasa, yang antara lain dikemukakan oleh Haugen 1978), Weinrich (1970), Mackey (1972), dan Appel \& Muysken (2006). Sementara itu, berkenaan dengan data yang diamati, Soetomo menelaah tentang interferensi, alih kode, dan kegandabahasaan.

Pada akhir penelitian yang datanya diambil dari penggunaan Bahasa Indonesia tulis para pengajar di Universitas Diponegoro Semarang itu, disimpulkan, antara lain, bahwa keintegrasian suatu unsur asing hanya dapat ditentukan oleh penutur bahasa dalam masyarakat 
yang bersangkutan karena rasa bahasa sebagai tolok ukurnya telah dipengaruhi oleh faktor sosial budaya yang melingkupinya. Di samping itu, disebutkan pula bahwa terus masuknya unsur asing ke dalam sistem bahasa Indonesia menandakan bahwa penyerapan konsep-konsep baru dari dunia Barat ke dalam BInd terus berlangsung.

Masalah kedwibahasaan dan integrasi perlu dikemukakan dalam bab ini karena keduanya memiliki hubungan erat dengan masalah utama dalam penelitian ini, yaitu interferensi. Kedwibahasaan merupakan suatu kondisi yang memungkinkan terjadinya interferensi, sedangkan integrasi merupakan hal yang sulit dipisahkan dari masalah interfernsi. Dengan demikian kedwibahasaan, integrasi, dan inteferensi secara berturut-turut akan dibahas berikut ini.

Dalam masyarakat Indonesia selain terdapat pemakaian Bahasa Indonesia, yang merupakan bahasa nasional, juga terdapat pemakaian bahasa daerah yang merupakan bahasa ibu sebagain besar penutur Bahasa Indonesia, sedangkan Bahasa Inggris sebagai bahasa asing bagi kelompok tertentu. Bahasa Inggri, karena merupakan bahasa asing pertama yang wajib dipelajari di sekolah, juga dikuasai oleh kelompok tertentu, utamanya para guru ataupun dosen bahasa Inggris. Hal ini memungkinkan sebagian masyarakat Indonesia mampu menguasai tiga bahasa: daerah, Indonesia, dan Inggris. Keadaan masyarakat yang demikian oleh para sosiolinguis lazim disebut masyarakat yang bilingual atau multilingual, masyarakat yang menguasai lebih dari satu bahasa (Soetomo, 1985).

Istilah bilingualitas mula-mula diperkenalkan oleh Bloomfield (1933). Pada permulaan abad ke-20 itu Bloomfield mengartikan kedwibahasaan sebagai penguasaan lebih dari sat bahasa seperti penutur aslinya (1933: 56). Sejak diperkenalkan oleh Bloomfield konsep ini terus berkembang. Haugen (1972) dan Applel \& Muysken (2006), misalnya, memperkembangkan makna kedwibahasaan sebagai kemampuan untuk memproduksi ujaran-ujaran yang berarti dalam bahasa lain. Jadi, menurut Haugen, kedwibahasaan tidak harus diukur dengan penggunaan, tetapi cukuplah dengan mengetahui kedua bahasa itu.

Berbeda dengan Haugen, Weinrich dalam Romaine (2000: 11) mengungkapkan perlunya "penggunaan" dalam praktik buntuk mengukur kedwibahasaan seseorang. Meskipun demikian, Weinrich sebenarnya menggunakan istilah kedwibahasaan dalam pengertian yang luas, tanpa memberikan ketentuan tingkat perbedaannya, baik keduanya berupa bahasa dan bahasa maupun dialek dalam bahasa yang sama. Menurut definisi Weinrich, kedwibahasaan adalah praktik penggunaan bahasa secara bergantian oleh individu yang sama.

Hampir senada dengan Weinrich, Mackey dalam Romaine (2000: 11) pengertian kedwibahasaan sebagai penggunaan dua bahasa atau lebih secara bergantian oleh individu yang sama. Selanjutnya, ia menyebutkan pula bahwa kedwibahasaan merupakan suatu konsep yang pengertiannya nisbi, yang di dalamnya terdapat masalah tingkat, fungsi, pertukaran, dan interferensi.

Berkenaan dengan hal tersebut Weinrich dalam Romaine (2000) menegaskan bahwa bahasa merupakan milik kelompok (masyarakat), sedangkan kedwibahasaan merupakan milik perseorangan. Sedangkan Oksaar (1992: 478) berpendapat bahwa kedwibahasaan harus diperlakukan sebagai gejala kelompok karena bahasa itu bukan sebagai alat perhubungan antar kelompok, melainkan juga faktor untuk menegakkan kelompok dan alat menunjukkan identitas kelompok.

Romaine (2000), berpendapat bahwa seorang dwibahasawan tidak harus menguasai kedua bahasa yang dimilikinya itu sama fasih, tetapi cukuplah, apabila ia dapat menyatakan diri dalam dua bahasa tersebut atau dapat memahami apa yang dikatakan atau ditulis dalam bahasa itu. 
Gambaran tersebut memperlihatkan bahwa kedwibahasaan merupakan fenomena kebahasaan dan sekaligus fenomena kemasyarakatan yang sifatnya nisbi. Meskipun demikian, umumnya disepakati bahwa kedwibahasaan adalah penguasaan dua bahasa oleh individu yang sama, baik secara aktif maupun pasif. Sementara itu, individu yag mampu menguasai kedua bahasa itu lazim disebut dwibahasawan.

Berkaitan dengan kedwibahasaan itu, Fishman (1972) dan Fredric (2011) menyebutkan ada empat macam situasi kebahasaan dalam masyarakat, yaitu: (1) adanya diglosia dan kedwibahasaan secara bersama-sama; (2) adanya kedwibahasaan tanpa diglosia; (3) adanya diglosia tanpa kedwibahasaan; (4) tidak adanya kedwibahasaan dan diglosia. Jika dilihat berdasarkan kerangka pikiran Fishman tersebut, tentulah situasi kebahasaan di Indonesia termasuk kelompok yang pertama, yakni terdapat kedwibahasaan dan sekaligus juga kediglosiaan.

Akibat dari masyarakat yang bilingual ataupun yang multilingual, dan ditambah dengan situasi kebahasaan yang diglosik itu, muncul berbagai fenomena kebahasaan yang, antara lain, berupa interferensi, alih kode, peminjaman unsur kebahasaan, dan peminjaman dengan pengubahan, baik secara lisan maupun secara tertulis. Hal itu tak terhindarkan karena dalam masyarakat semacam itu terjadinya kontak bahasa tidak dapat dielakkan.

Sebagaimana definisi Weinrich dalam Romaine (2000) bahwa inteferensi adalah suatu betuk penyimpangan dalam penggunaan bahasa dari norma-norma yang ada sebagai akibat adanya kontak bahasa atau pengenalan labih dari satu bahasa. Dalam rumusnya yang lain, ia menyebutkan bahwa penggunaan unsur bahasa yang satu pada bahasa yang lain ketika berbicara atau menulis juga dapat disebutkan interferensi. Selanjutnya, pengertian yang diberikan oleh Weinrich itu diikuti dalam penelitian ini.

Dalam proses intereferensi, pemakaian bahasa tidak sepenuhnya mengikuti kaidah, tetapi mengalami penyimpangan karena adanya pengaruh dari bahasa lain. Dalam masyarakat yang bilingual ataupun masyarakat yang multlingual, seperti Indonesia, penyimpanganpenyimpangan seperti itu merupakan gejala kebahasaan yang hampir bersifat umum.

Dalam proses perubahan dan perkembangan bahasa, menurut Appel \& Muysken (2006), interferensi sangat berperan. Ia mengemukakan lebih lanjut bahwa interferensi merupakan gejala perubahan yang terbesar, terpenting, dan paling dominan dalam perkembangan suatu bahasa. Dalam bahasa yang besar, seperti Bahasa Inggris pun, perkembangannya tidak dapat dilepaskan dari gejala interferensi.

Berkenaan dengan proses interferensi, menurut Soetomo (1985), terdapat tiga unsur pokok, yaitu bahasa sumber atau bahasa donor, bahasa penerima atau respien, dan unsur serapan atau importasi. Dalam komunikasi nyata, bahasa yang menjadi sumber serapan pada saat tertentu dapat beralih peran menjadi bahasa penerima pada saat yang lain, dan demikian pula sebaliknya. Bahasa penerima pun pada saat yang lain dapat berperan sebagai bahasa penerima. Akibatnya, interferensi itu dapat terjadi secara timbal balik.

Antara Bahasa Indonesia dan Bahasa Jawa, misalnya, pada saat tertentu Bahasa Jawa itu akan menjadi bahasa sumber penyerapan bagi Bahasa Indonesia. Dalam kondisi yang demikian akan terjadi interferensi Bahasa Jawa dalam Bahasa Indonesia itu akan beralih peran menjadi bahasa sumber bagi Bahasa Jawa. Dalam kondisi yang seperti ini yang terjadi adalah interfernsi Bahasa Indonesia dalam Bahasa Jawa.

Sejalan dengan pendapat Weinrich (1970) dalam Romaine (2000), terjadinya interferensi dalam suatu bahasa, antara lain, disebabkan oleh faktor sebagai berikut: (1) kedwibahasaan para peserta tutur; (2) tipisnya kesetiaan pemakai bahasa penerima; (3) tidak cukupnya kosakata bahasa penerima dalam menghadapi kemajuan dan pembaruah; (4) menghilangnya kata-kata 
yang jarang digunakan; (5) kebutuhan akan sinonim; (6) prestise bahasa sumber dan gaya bahasa. Di samping itu, ditambahkan oleh Hartman dan Stork (1972: 155) bahwa interferensi terjadi pula karena terbawanya kebiasaan dari bahasa pertama atau bahasa ibu.

Obyek dalam penelitian ini adalah pemakaian Bahasa Inggris dalam buku ajar, yang para penulisnya memiliki latar belakang dwibahasawan, Bahasa Indonesia dan Bahasa Inggris. Selain itu, kekurang sempurnaan dalam penguasaan bahasa Inggris tersebut diduga juga menjadi salah satu faktor yang merangsang timbulnya interferensi.

Berdasarkan alasan tersebut, masalah interferensi Bahasa Indonesia dalam Buku Lembar Kerja Siswa berbahasa Inggris diteliti secara intensif dalam penelitian ini. Di samping alasan diatas, alasan lain yang mendorong dilakukannya penelitian in adalah adanya anggapan umum yang menyebutkan bahwa pengaruh Bahasa Indonesia dalam bahasa Ingris cukup besar. Hal ini dapat difahami bahwa Bahasa Indonesia merupakan bahasa nasional yang sangat dikuasai oleh para penulis buku ajar. Namun, seberapa pengaruh itu, khususnya yang berupa interferensi tersebut belum dapat diketahui secara pasti dan diperlukan penelitian untuk mengungkapnya.

Berdasarkan latar belakang tersebut, masalah yang diamati dalam penelitian ini adalah sebagai berikut. (1) Apa saja tipe interferensi gramatikal yang terdapat pada buku LKS Bahasa Inggris untuk SMP di Surakarta? (2) Berapa frekuensi interferensi gramatikal pada masingmasing tipe tersebut? (3) Faktor apa saja yang menyebabkan munculnya interferensi gramatikal tersebut.

\section{METODE PENELITIAN}

Obyek penelitian ini adalah interferensi BInd ke dalam BIng yang terdapat di buku LKS ber-BIng untuk SLTP kelas I di Surakarta. Kurang lebih ada sepuluh judul buku LKS, yaitu Professional BIng (PT Mediatama Surakarta), LKS BIng (CV Pustaka Mulia, Surakarta), Rabel (Rajin Belajar) Bahasa Inggris (Cahaya Ilmu Surakarta), Progressive Bahasa Inggris (CV Widya Duta Surakarta), Kejar (kegiatan Belajar) Bahasa Inggris (Penerbit PT Pabelan Surakarta), Gemilang Bahasa Inggris (Penerbit CV Harapan Baru Surakarta), Komunikasi aktif Bahasa Inggris (Penerbit Tiga Serangkai Surakarta), Sportif (Sarana Belajar siswa Aktif) Bahasa Inggris (Penerbit Cahaya Ilmu Surakarta), LKS Bahasa Inggris (asosiasi MGMP \& Guru inti Bahasa Inggris di Surakarta).

Data penelitian ini adalah kalimat-kalimat yang mengandung interferensi dalam bukubuku LKS bahasa Inggris SLTP Kelas I Semester II. Pemilihan buku LKS Semester II didasarkan pada kenyataan bahwa buku tersebutlah yang beredar dipasaran dan tersedia di sekolah-sekolah. Penebit biasanya hanya mencetak buku LKS khusus untuk satu catur wulan tertentu. Sebagai sumber datanya adalah reading texts dan dialog dari semua buku LKS Bahasa Inggris tersebut.

Teknik pengumpulan data yang dipakai dalam penelitian ini adalah teknik simak dan catat. Peneliti membaca dengan seksama kemudian mencatat atau mendokumentasikan semua kalimat yang mengandung interferensi dari sumber data yang telah ditentukan. Adapun untuk menentukan kalimat-kalimat yang bisa dijadikan sebagai data, peneliti menggunakan framework dari James (2014). Semua kalimat yang telah tercatat akan disusun dalam daftar dan dipakai sebagai data primer dalam penelitian ini.

Data yang telah tekumpul selanjutnya akan dianalisis dengan menggunakan metode deskriptif eksplanatif dari James. Pada prinsipnya ada tiga tahapan utama dalam analis ini yaitu: recognition, classification, and explanation (James, 2014). Secara lengkap prosedurnya dapat digambarkan sebagai berikut.

Pertama, data yang telah terkumpul lewat identifikasi kemudian diklasifikasikan berdasarkan bentuk liguistik untuk dapat dilihat pada tataran mana interferensi terjadi. Kedua 
adalah kalkulasi dari masing-masing tataran linguistik untuk memperoleh gambaran frekuensi terjadinya interferensi. Peneliti juga akan menyajikan interferensi pada tataran apa yang paling dominan, dan sekaligus buku mana yang paling banyak mengandung unsur interferensi. Tahap terakhir adalah pembahasan faktor-faktor yang merupakan sumber munculnya interfernsi gramatikal tersebut.

\section{HASIL DAN PEMBAHASAN}

Segbagaimana permasalahan interferensi yang telah disebutkan sebelumnya, pada bagian ini akan dipaparkan hasil analisis yang merupakan jawaban dari permasalahan yang telah diajukan, yaitu meliputi jenis-jenis interferensi gramatikal, frekuensi dan total interferensi, serta faktor yang mempengaruhi interferensi.

\section{Jenis-Jenis Interferensi Gramatikal}

Sebagaimana telah disampaikan sebelumnya bahwa interferensi BInd ke dalam BIng yang terdapat dalam buku LKS berupa interferensi leksikan dan gramatikal. Interferensi gramatikal dapat pula disebut sebagai interferensi sintaksis; interferensi ini ditemukan dalam srtuktur bahasa Inggris. Dalam hal ini penulis buku LKS menggunakan tata bahasa Indonesia dalam bahasa Inggris. Hal demikian biasa dijumpai pada kalangan pembelajar bahasa asing, pembelajar menggunakan kemampuan kebahasaan yang terbatas untuk menyampaikan idenya dalam bahasa target. Sebagai akibatnya terjadilah interferensi dari bahasa yang sangat dikuasainya ke dalam bahasa yang sedang dipelajari.

Analisis data menunjukkan bahwa keterbatasan kemampuan dalam berbahasa Inggris mengantarkan penulis buku LKS untuk menggunakan kebiasaan lama (ber BInd) dalam kebiasaan baru (ber BIng) yang menyebabkan munculnya interferensi. Akibat terjadinya interferensi ini memunculkan kalimat yang tidak tepat dalam ber BIng. Ketidaktepatan kalimat tersebut karena beberapa sebab, antara lain adanya mismatch of lexical system, ekspresi yang berlebih (superflous expression), interferensi dalam penggunaan preposisi, Konstruksi paralel, konstrukdi pasif, konjungsi, dan penggunaan kata keterangan.

\section{Ketidakcocokan pada Sistem Leksikon (Mismatch of Lexical System)}

Interferensi gramatikan BInd ke dalam BIng terjadi dalam bentuk mismatch of lexical system, ketidak cocokan dalam sistem urutan kata dan tautan kata dalam bahasa Inggris. Misalnya dalam kalimat the weather felt cold, kata weather tidak dapat dipadukan dengan kata felt, karena cuaca tidak dapat merasakan. Manusialah yang dapat merasakan cuaca panas atau dingin. Maka dalam bahasa Inggris kalimat dapat berbunyi I felt cold. Namun, tidak demikian halnya dalam BInd, contoh kalimat diatas dapat dikatakan sebagai perpaduan kata yang tepat, cuaca terasa dingin, tidak ada yang salah dengan kalimat ini.

Data memperlihatkan banyak kalimat yang dakategorikan sebagai mismatch of lexical system, sebagaimana dilustrasikan pada kalimat berikut.

It rained day after day, the *weather felt cold. cuaca terasa

After *praying Idul Fitri, I want to visit [...]. sholat Idul Fitri

Tuti was sick, *her body was hot. badannya panas 


\section{Superflous Expression}

Interferensi gramatikal dari Bahasa Indonesia ke dalam BIng juga terdapat pada konstruksi BIng yang Superflous atau berlebihan. Misalnya dalam konstruksi according to your opinion, kata according to tidak dapat dihadirkan untuk mendamping kata opinion, bahkan mubazir. Namun, tidak demikian halnya dalam BInd, konstruksi tersebut (menurut pendapatmu) dapat dikatakan sebagai cukup, tidak berlebih.

Analisis data memperlihatkan banyak kalimat yang dakategorikan sebahgai Superflous Expression, sebagaimana dicontohkan pada kalimat berikut.

We practice $[\ldots] *$ to make a show $[\ldots]$.

for a show

After we finish the opening ceremony, $[\ldots]$ and $*$ begin to do some exercises.

begin

*According to your opinion, how people here live?

In your opinion

\section{Preposisi}

Bahasa Inggris memiliki preposisi yang jumlahnya jauh lebih banyak dari Bahasa Indonesia. Sebagai contoh preposisi di yang mengacu pada tempat dan waktu dapat dijadikan padanan bagi beberapa preposisi dalam Bahasa Inggris: in, at, on, misalnya "di rumah/at home", "di Indonesia/in Indonesia", "di hari minggu/on sunday. Kondisi inilah yang juga sering membuat penulis buku LKS kembali pada kebiasaan lama, menggunakan kaidah kebahasaan BInd dalam ber-BIng, yang mengakibatkan terjadinya interferensi BInd ke dalam BIng, khususnya dalam pemakaian preposisi. Kasus serupa dapat dilihat pada contoh data kalimat berikut.

He is good $*$ in all subjects.

at

A chess board with chessmen is * between them.

in front of

[...] because he agrees *about Irfan's hobby.

with

\section{Konstruksi Paralel}

Dalam BIng untuk mengatakan tentang dua (atau lebih) tindakan atau keadaan dalam satu klausa digunakan dua atau lebih klas kata yang dihubungkan dengan konjungsi. Kata-kata tersebut harus dalam satu kelas dan bentuk yang sama, misalnya He is rich and kind. Kata sifat rich (kaya) harus paralel dengan kata sifat kind (ramah). Namun, tidak demikian halnya dengan BInd. Ide kalimat tersebut dapat diindonesiakan menjadi Dia kaya dan memilki banyak teman, kata sifat kaya dapat bebas bedampingan dengan kata kerja memiliki. Hal inilah yang juga menjadi penyebab terjadinya interferensi BInd ke BIng, khusunya yang melibatkan konstruksi yang paralel. Analisis data menunjukkan beberapa kasus serupa yang dapat dicontohkan pada kalimat berikut.

Camping is * cheap and has a lot of fun.

$$
\text { fun }
$$




\section{[...] to make a program and $*$ it can be used to play games to play games \\ [...] such as serving *food, drinking, and cleaning. and drink}

\section{Konstruksi Pasif}

Pada umumnya konsep pembentukan konstruksi pasif dalam BIng dapat dipelajari dengan mudah. Namun, tidak demikian halnya dengan cara pemakainnya dalam kalimat yang memang berbeda dari bentuk passive dalam bahasa Indonesia. Dalam BInd kalimat bentuk pasif sangat jamak digunakan, tetapi tidak dalam BIng. Didalam BIng kalimat pasif sering digunakan utamanya untuk menyampaikan ide yang pelakunya sudah pasti dan tertentu, misalnya seorang pencopet ditangkap, kalimat ini sudah menyiratkkan bahwa pelakunya adalah polisi. Kebiasan penggunaan bentuk pasif dalam BInd seperti ini sering terbawa dalam penggunaan BIng. Konsekuensinya adalah kalimat bIng yang muncul menjadi tidak tepat walaupun secara gramatikal dapat diterima (wellform but unacceptable). Data menunjukkan interfernsi gramatikal khususnya dalam penggunaan passive voice sebagaimana contoh berikut ini.

It $*$ can be done indoors and outsoors They do it

Any marbles near it ${ }^{*}$ will be beaten by the tiger. The tiger will beat any marbles near it

[...] The traditional games * began to be played. People began to play the traditional games.

\section{Konjungsi}

Mengkombinasikan kalimat nampaknya merupakan salah satu problem yang dihadapi oleh penulis buku LKS. Kesulitannya sering terletak pada penggunaan conjunction yang tidak tepat dan hadirnya conjunction yang tidak perlu. Kesulitan semacam itu ditanggulangi dengan cara menggantungkan pada sistem kebahasaan yang sudah dikuasainya, BInd. Akibatnya, muncullah interferensi BInd ke dalam bahasa Indionesia pada penggunaan konjungsi. Konstruksi kalimat Nama saya Ira Damaiyanti tetapi orang memanggilku Ira, mungkik tidak terasa janggal, tetapi tentu hal ini tidak dapat diterima dalam BIng. Konjungsi tetapi disini kurang tepat, seharusnya dan

Analisis data menunjukkan ada beberapa kostruksi kalimat yang menujukkan interferensi Bind ke dalam BIng, khususnya dalam penggunaan konjungsi, sebagaimana kalimat berikut.

My name Ira Damaiyanti *but people call me Ira.

and

I hate football *and I enjoy reading

but

I am well, thank you, Ron, *but how are you?

and 
It's better * if we play games there.

for us to

\section{Penggunaan Kata Keterangan}

Dalam BIng untuk mengatakan suatu lingkungan kejadian atau situasi dapat digunakan adverb atau modifier. Adverb digunakan untuk menerangkan clause sedangkan modifier untuk menerangkan kata atau frasa. Kaidah BIng sudah mengatur secara pasti dimana posisi atau letak adverb maupun modifier untuk menerangkan kata, frasa, maupun klausa. Kaidah semacam itu dalam bBahasa Indonesia tidak begitu rigit, sehingga kata keterangan dapat diposisikan dimana saja. Misalnya "Kemarin saya pergi ke Jakarata”, "Saya pergi ke Jakarta kemarin", "Pergi ke Jakarta saya kemarin", dst. Dalam BIng konstruksi tersebut harus "I went to Jakarta yesterday" atau "Yesterday I went to Jakarta".

Data menunjukka interferensi BInd ke dalam BIng juga terdapat dalam hal penggunaan kata keterangan. Penulis menggunakan kebiasaan ber-Bind dalam ber-BIng dalam hal menempatkan kata keterangan sebagaimana contoh berikut.

* Covering his eyes one of them stands in the middle $[\ldots]$
one of them, with cover on his eyes, stands ... or
with eyes covered with a cloth one of them ...
* People should like reading especially children because $[\ldots]$
people, especially children, should like reading
* Too long in front of the computer can damage the eyes.
You can damage your eyes $[\ldots]$ in front of the computer too long

Tabel 1: Interferensi Gramatikal BInd ke dalam BIng

\begin{tabular}{clcc}
\hline No. & \multicolumn{1}{c}{ Kategory } & Jumlah Kasus & $\mathbf{\%}$ \\
\hline 1. & Mismatching & 62 & 33.51 \\
3. & Preposition & 35 & 18.91 \\
4. & Superflous Expression & 27 & 14.59 \\
5. & Parallel Construction & 21 & 11.35 \\
6. & Passive & 17 & 9.18 \\
7. & Conjunction & 14 & 7.56 \\
8. & Modifier / Adverb & 9 & 4.86 \\
\hline \multicolumn{2}{r}{ Jumlah } & 185 & 100
\end{tabular}

\section{Total Interferensi Gramatikal Masing-Masing Buku LKS}

Sebagaimana telah disampaikan pada bagian terdahulu bahwa sumber data dari penelitian ini adalah sepuluh buku Lembar Kerja Siswa (LKS) Bahasa Inggris untuk SLTP di Surakarta. Dari seluruh buku LKS teresebut berhasil dikumpulkan kasus interferensi yang bisa dikategorikan sebagai interferensi gramatikal.

Hasil analisis menunjukkan bahwa hampir seluruh buku LKS tersebut mengandung kasus interferensi yang cukup variatif. Khusus dalam bagian ini, akan dipaparkan jumlah total inteferensi masing-masing buku LKS. Dari paparan inilah akan diperoleh gambaran yang jelas tentang buku LKS mana yang paling banyak mengandung interferensi dan mana yang paling sedikit. 
Jumlah total kasus interferensi gramatikal dari kesepuluh buku LKS adalah 185. Total interferensi yang paling banyak ditemukan pada Rabel (Rajin Belajar) Bahasa Inggris untuk SLTP, yaitu, 45 kasus (24,32\%). Kesalahan terbanyak kedua setelah Rabel ditemukan pada buku LKS Bahasa Inggris untuk SLTP (Hadira) 32 kasus atau 17.28\%. Kedudukan ketiga ditempati oleh LKS Bahasa Inggri untuk SLTP (Pustaka Mulia) 27 kasus atau 14,59\%. Selanjutnya kesalahan terbanyak setelah LKS Bahasa Inggris (Pustaka Mulia) telah terekam untuk Gemmilang Bahasa Inggris untuk SLTP, yaitu, 25 kasus atau 13,51\%.

Kemudian interferensi yang cukup signifikan ditemukan pada buku LKS Professional Bahasa Inggris, sejumlah 18 kasus atau 9.72\%. Interferensi yang juga signifikan ditemukan pada Buku LKS Kejar Bahasa Inggris sejumlah 16 kasus atau 8.65\%. Sportif menduduki posisi setelah Kejar dalam hal banyaknya kesalahan. Hasil analisis menemukan 13 kasus atau 7.02\%. Kemudian diikuti oleh Progresif Bahasa Inggris dengan interferensi 8 kasus atau 4.32\%.

Komunikasi aktif Bahasa Inggris terbukti memiliki interferensi yang tidak signifikan. Hasil analisis menemukan hanya 1 kasus atau 1, 0.54\%. Dan yang terakhir LKS Bahasa Inggris (MGMP) terbukti tidak mengandung interferensi, $0 \%$.

Perbandingan interferensi pada masing-masing buku LKS dapat dilihat pada tabel berikut ini.

Tabel 2: Interferensi Gramatikal Masing-Masing Buku LKS

\begin{tabular}{clcc}
\hline No. & Nama Buku LKS & $\begin{array}{c}\text { Jumlah } \\
\text { interferensi }\end{array}$ & \% \\
\hline 1. & Rabel & 45 & 24.32 \\
2. & Bahasa Inggris (Hadira) & 32 & 17.28 \\
3. & LKS (Pustaka Mulia) & 27 & 14.59 \\
4. & Gemilang & 25 & 13.51 \\
5. & Profesional & 18 & 9.72 \\
6. & Kejar & 16 & 8.65 \\
7. & Sportif & 13 & 7.02 \\
8. & Progresif & 8 & 4.32 \\
9. & Komunikasi Aktif & 1 & 0.54 \\
10. & LKS (MGMP) & 0 & $0 \%$ \\
\multicolumn{2}{r}{ Jumlah } & 185 & $100 \%$ \\
\hline
\end{tabular}

\section{Faktor-Faktor yang Mempengruhi Interferensi}

Guna memaparkan faktor yang mempengaruhi interferensi, peneliti akan menggunakan kerangka Weinrich (1970: 64-65) dan Hartman dan Stork (1972: 155). Hasil analisis menunjukkan bahwa inteferensi BInd kedalam BIng yangterdapat pada buku LKS antara lain dipengaruhi oleh kedwibahasaan penulis buku dan terbawanya kebiasaan dalam bahasa ibu.

\section{a. Kewibahasaan Penulis Buku LKS}

Kewibahasaan peserta tutur dalam hal ini para penulis buku LKS merupakan pangkal terjadinya interferesi. Dikatakan demikian karena di dalam diri para penutur yang dwibahasawan itulah tempat terjadinya kontak atau persentuhan bahasa, yang pada akhirnya akan menimbulkan interferensi. Berkenaan dengan penelitian ini, kontak yang terjadi adalah antara BInd dan Ing. Dalam kasus interferensi yang terjadi dari BInd ke dalam BIng lebih dominan disebabkan penutur lebih menguasai BInd dari pada BIng (subordinate Bilingual). Para penulis buku para guru SLTP setempat yang mengausi bahasa Indonesia disamping bahasa Jawa sebagai bahasa pertamanya. Sebagai guru maka BInd 
merupakan bahasa pengantar formal yang digunakan dalam lingkungan akademiknya. Mereka mempelajri BIng sebagai bahasa asing. Dengan demikian jelaslah bahwa mereka lebih menguasai Bahasa Indonesia dari pada bahasa Inggris.

\section{b. Terbawanya Kebiasaan dalam Bahasa Ibu}

Terbawanya kebiasaan dalam bahasa ibu (BInd) pada bahasa penerima (BIng) yang sedang digunakan selain terjadi karena kurangnya kontrol bahasa, juga karena kurangnya penguasaan terhadap bahasa penerima. Alasan kedualah yang nampaknya terjadi pada para penulis buku LKS dalam kajian ini. Dalam penggunaan bahasa Inggris tiba-tiba yang muncul dalam benaknya adalah unsur-unsur bahasa Indonesia yang sudah sengat dikenalnya dan juga sangat dikuasainya. Hal itu karena tingkat penguasaan bahasa oleh dwibahasawan tidak seimbang.

Perbedaan tingkat penguasaan bahasa itu telah menyebabkan penulis mengalami kesulitan dalam menggunakan bahasa Inggris yang kurang dikuasainya. Hal itu mengakibatkan dwibahasawan meminjam unsur-unsur bahasa yang lebih dikuasainya, yang dalam hal ini bahasa Indonesia.

Hasil penelitian juga menunjukkan bahwa banyak unsur pinjaman Bind pada tataran gramatikal. Para penulis buku teks telah menggunakan pengetahuan ketatabahasaan Indonesianya untuk menyampaikan ide dalam bahasa Inggris. Dengan kata lain mereka memanfaatkan pengalaman mereka berbahasa Indonesia untuk mengorganisasikan data bahasa target dalam grammar.

Saat mencoba untuk mengeksprtesikan ide yang dikehendaki, penulis buku teks seringkali menggunakan tatabahasa Indonesia ke dalam bahasa Inggris yang sering berakibat pada ekspresi yang berlebih (Superflous Expression) dan ketidak sesuaian dalam sistem leksikal (Mismatch of Lexical System) seperti kalimat According to your opinion how do people $[\ldots]$ ?

Perlu diingat bahwa dalam bahasa Indonesia ada wilayah kosakata yang memiliki padanan langsung dalam bahasa Inggris dan ada wilayah yang tidak. Dengan demikian model transfer gramatikal yang tidak memperhatikan konteks hasilnya tidak tepat. Misalnya hal itu dapat mengakibatkan munculnya superflouse expression serta munculnya mismatch of lexical system sebagaimana contoh frasa "tight cooperation" dan "a clever tailor". Dalam frasa ini, penulis buku LKS telah melanggar aturan semantis yang tidak mungkin muncul dalam tulisan atau ujaran yang benar. Mereka menulis frase tanpa mengaitkan hubungan semantis pada kata-kata yang dipadukan seperti tight dan cooperation, clever dan tailor.

Hasil analisis menunjukkan adanya transfer gramatikal yang digunakan oleh penulis buku teks dalam wilayah yang lain seperti Ptronoun, conjunction, pessive voice, adverb dan modifier, serta preposition, berikut masing-masing contohnya.

People here like to work together and to help others. We live in harmony. Kalimat ini ditransfer dari Masyarakat disini senang bergotong royong. Kita hidup harmonis. Sedangkan penggunaan konjungsi, sebaimana dalam kalimat "Anjing itu ramah tapi juga penjaga yang baik" dan "The dog is friendly, but it is a good guard". Dalam kalimat diatas, penulis buku LKS mencoba untuk membuat kalimat majemuk yang terdiri dari dua klausa dan digabungkan dengan sebuah conjunction. Bahasa Inggris dan bahasa Indonesia sama sama memiliki properti untuk itu. Bahasa Inggris memiliki peraturan yang ketat dalam penggunaan conjunction ini. Sehingga pengguna bahasa akan mudah menilai apakah conjunction yang digunakan itu tepat atau tidak. Sebaliknya dalam bahasa Indonesia orang seringkali kurang mewaspadai apakah conjunction yang dipakai tepat atau tidak. Dalam komunikasi sehari-hari orang bisa saja menerima kalimat yang mengandung conjunction 
tidak tepat, seperti "Anjingku ramah, tetapi juga penjaga yang baik", dan "Namaku Ira Damayanti, tetapi orang memanggilku Ira".

Transfer dalam penggunaan pasif sebagai mana kalimat "Festival was followed by popular dances", (Ind: Festival diikuti oleh para penari terkenal). Kalimat ini menggambarkan kebiasaan penulis bertutur dalam kalimat pasif dalam bahasa ibu mereka terbawa dalam pengalaman baru mereka, yaitu berbahasa Inggris. Dulay, Burt, and Kashen (1981) menyebutkan fenomena ini dengan negative transfer. Disini penulis buku menggunakan ilmu kebahasaan bahasa ibu yang telah sangat dikuasai untuk mengekspresikan ide dalam bahasa Inggris. Pada umumnya memang pembelajaran bahasa Inggris sangat mudah memahami bentuk-bentuk pada passive, tetapi sering kesulitan dalam pengaplikasiannya. Kalimat bahasa Inggris passive yang benar secara grammatikal belum tentu benar penggunaann, sehingga kalimat "Festival was followed by popular dancers" adalah benar menurut grammar tetapi tidak berterima.

Transfer dalam penggunaan adjunct dan mdifier seperti dalam kalimat "Now in some certain areas farmers begin using tractors to cultivate the rice". Adjunct adalah keterangan yang biasa melekat pada sebuah klausa, sedangkan modifier melekat pada sebuah frasa. Dalam bahasa Inggris peraturan mengenai posisi penempatan kedua komponen dalam kalimat sangat ketat, sedangkan dalam bahasa Indonesia tidak. Selain itu, ada kesamaan dan perbedaan dalam penggunaannya antara bahasa Inggris dan bahasa Indonesia. Bila kebetulan dalam posisi yang sama maka tidak akan terjadi interferensi sedang bila berbeda posisinya kemungkinan akan muncul interferensi.

Interferensi ini disebabkan adanya perbedaan posisi adjunct maupun modifier dalam bahasa Inggris dan bahasa Indonesia, atau sering disebut negative transfer. Bagi telinga pengguna bahasa Indonesia, kalimat berikut ini akan terasa benar dan berterima, namun padanannya dalam bahasa Inggris harus mengikuti konstruksi yang sudah ditentukan. Perhatikan kalimat ini:

Sekarang di beberapa daerah para petani menggunakan traktor.

Para petani di beberapa daerah sekarang menggunakan traktor.

Di beberapa daerah sekarang para petani menggunakan traktor.

Di beberapa daerah para petani sekarang menggunakan traktor.

Di beberapa daerah para petani menggunakan traktor sekarang.

Di dalam BIng, adverbia harus diletakkan pada pada posisi yang tetap untuk menghindari ambiguitas. Kata nowadays sebagai keterangan waktu harus berada pada awal atau akhir kalimat. Frase in some areas adalah keterangan dari kata farmers, maka harus diletakkan sasudah kata itu. Sehingga kalimat yang tepat dalam BIng adalah "Nowadays farmers in some areas use tractors" atau "Farmers in some areas use tractors nowadays."

Berikutnya adalah transfer dalam penggunaan preposisi, seperti pada kalimat "We practice volley ball twice a week in Monday and Thursday" dan "Mr. And Mrs. Sutomo were very proud with the sociality of the doctors and nurses". Kalimat ini menggambarkan bahwa penggunaan preposisi ini mereka telah termotivasi oleh pengetahuan kebahasaan bahasa Indonesianya. Kata proud with adalah ekuivalensi dari bangga dengan. Padanan langsung kata dengan adalah with. Maka penulis buku teks proud with dan bukan proud of. Sama halnya dengan kata afraid to yang merupakan ekuivalensi dari takut kepada. Kata kepada memiliki padanan langsung to, maka penulis buku teks menuliskan dengan afraid to dan bukan afraid of. 


\section{KESIMPULAN DAN SARAN}

Berdasarkan hasil peperan penelitian di atas, dapat disimpulkan bahwa bahwa keterbatasan penguasaan bahasa Inggris telah mengantarkan penulis buku LKS untuk menggunakan kebiasaan lama (ber BInd) dalam kebiasaan baru (ber BIng) dengan cara mengambil unsus gramatikal BInd untuk digunakan dalam BIng. Hal demikian telah menyebabkan munculnya interferensi gramatikal. Interferensi gramatikal ini meliputi mismatch of lexical system, superflous expression. Misalnya dalam kalimat the weather felt cold dan according to your opinion. Interferensi BInd ke dalam BIng ini juga terjadi dalam beberapa komponen grammer lainnya seperti penggunaan preposisi, paralell construction, penggunaan bentuk pasif, penggunaan konjungsi, dan penggunaan adverb maupun modifier untuk menerangkan kata, frasa, maupun klausa.

Kaitannya dengan faktor yang mempengaruhi interferensi, analisis menunjukkan bahwa inteferensi BInd kedalam BIng yang terdapat pada buku LKS antara lain dipengaruhi oleh kedwibahasaan penulis buku, adanya gap antara khazanah Kosakata BInd dan BIng, serta terbawanya Kebiasaan dalam Bahasa Ibu. Kedwibahasaan peserta tutur dalam hal ini para penulis buku LKS merupakan pangkal terjadinya interferesi, karena di dalam diri para penutur yang dwibahasawan itulah tempat terjadinya kontak atau persentuhan bahasa, yang pada akhirnya akan menimbulkan interferensi.

Perbedaan tingkat penguasaan bahasa itu telah menyebabkan penulis mengalami kesulitan dalam menggunakan bahasa Inggris yang kurang dikuasainya. Hal itu mengakibatkan dwibahasawan meminjam unsur-unsur bahasa yang lebih dikuasainya, yang dalam hal ini bahasa Indonesia.

Dalam unsur pinjaman BInd pada tataran gramatikal, mereka memanfaatkan pengalaman mereka dalam berbahasa Indonesia untuk mengorganisasikan data bahasa target. Interferensi semacam itu telah berakibat pada munculnya ekspresi yang berlebih (Superflous Expression) dan ketidak sesuaian dalam sistem leksikal (Mismatch of Lexical System). Interferensi gramatikal juga muncul dalam penggunaan conjunction, passive, adjunct dan mdifier, dan preposisi.

Uraian di atas menunjukkan bahwa bahasa Inggris yang digunakan dalam buku LKS banyak dipengaruhi oleh bahasa Indonesia. Interferensi semacam itu dapat dikategorikan sebagai penyimpangan dan menunjukkan bahwa BIng yang digunakan banyak mengandung kesalahan atau penyimpangan. Oleh karenanya beberapa saran berkaitan dengan penggunaan buku LKS Bahasa Inggris di SLTP dapat kami sampaikan sebagai berikut:

1. Guru pengampu Bahasa Inggris seyogyanya mengkonsultasikan terlebih dahulu buku LKS yang akan diberikan kepada para siswa, sehingga mereka yakin benar kelayakan buku tersebut untuk dijadikan sebagai buku ajar.

2. Para penulis buku LKS seyogyanya mengkonsultasikan hasil tulisannya kepada orang yang lebih kompeten sebelum mencetak dan menyebarluaskannya kepada para pengguna (siswa).

3. Keberadaan MGMP dirasa cukup positif guna meningkatkan kompetensi para guru Bahasa Inggris dan selayaknyalah para guru berpartisipasi aktif dalam organisasi ini.

\section{DAFTAR PUSTAKA}

Appel, R. and Muysken. 2006. Language Contact and Bilingualism. Amsterdam: Amsterdam University Press

Bloomfild, L. 1993. Language. New york: Holt Rinehart.

Fishman, J.A. 1972. Sociolinguistics: A Brief Introduction. Rowley. Massachusetts: Newbury House. 
Fredric, F. 2011. Bilingualism in the USA: The Case of the Chicano-Latino Community. John Benjamins.

Halliday, M.A.K. 1970. "The Users and Uses of language". in Fishman (Ed.) Readings in the Sociology of language. Paris: The Hague, Mouton.

Hartman, R.R.K. and F.C. Stork. 1972.Dictionariey of Language and Linguistics. London: Applied Science Publishers.

Haugen. 1978. "Linguistics and Dialinguistics" in Alatis, James E. (Ed.) Bilingualism and Language Contact. Washington DC. Georgetown University Press.

James, C. 2014. Errors in language learning and use: Exploring Error Analysis: Applied linguistics and language study series. London: Rutledge.

Mackey, W. 1970. The description of bilingualism. In Fishman, J. (Ed.). Readings In The Sociology Of Language, 2nd ed., (pp. 555- 584). The Hague: Mouton \& Co.

Oksaar, E. 1992. "Intercultural Communication in Multilingual Settings". International Journal of Applied Linguistics. 2/1: 3-16

Romaine, Suzanne. 2000. Bilingualism. Oxford: Blackwell.

Weinreich, U. 1968. Language in Contact: Findings and Problems. New York: The Hauge, Mouton. 